\title{
The Neurology of Art - The Example of Giorgio de Chirico
}

\author{
Julien Bogousslavsky \\ Department of Neurology, University Hospital, Lausanne, Switzerland
}

Neurological case reports on famous artists can be particularly educational and instructive. However, critical clinical data are often lacking so that the final diagnosis may remain controversial. For example, the French composer Maurice Ravel has been successively thought to have suffered from stroke, subdural hematoma, Alzheimer's disease, corticobasal degeneration and, more recently, focal brain atrophy, which was even suggested to be renamed Ravel's disease [1]! In the present issue of the Journal, Blanke and Landis [2] make a very convincing point that Giorgio de Chirico, one of the major painters of the twentieth century, had temporal lobe epilepsy rather than migraine with aura as previously suggested $[3,4]$.

Indeed, while some patterns in his art (such as pool water in the series Bagni misteriosi) may well be reminiscent of scintillating scotoma, de Chirico's personal history and his work, starting with the 'metaphysical' paintings and drawings, do not suggest unequivocally that he was familiar with migraine attacks. Blanke and Landis [2] underline that de Chirico had only two episodes of recorded headaches, which occurred in 1905 and 1906, much before he devoted himself to painting. Besides, de Chirico's episodes with abdominal malaise of sudden onset and short duration, and his self-reporting of complex visual and gustatory hallucinations are also more suggestive of partial complex seizures than of migrainous events.

De Chirico made no secret that he was transposing into his work several of his hallucinatory experiences, as reported by himself in his book Hebdomeros [5] and in his memoirs [6]. Complex onirical representations, coexisting features from several periods of history (starting from antiquity), and the intrusion of apparently unrelated objects (gloves, bananas, artichokes, displayed in a Renaissance piazza) are in contrast with the absence of the deformations and blurring of objects which characterize migraine aura. The superimposition of several realities, without any confusion between them, in the very same object (e.g. abdomen and trunk of persons filled with antique temples and ruins, pictures into pictures) are also much more suggestive of the complex visual imagery of partial seizures than the simple, stereotyped, often 'abstract', visual deformations of migraine.

Although nonspecific, the reportedly ultra-rigid, 'viscous', mysterious personality of de Chirico is also compatible with interictal states associated with temporal epilepsy. This is well exemplified in his work, especially from his metaphysical period, where enigma obsessions and repetitivity abound, with series of paintings centered on perseverating themes (such as Ariadne, towers, arcades, trains, the statue man, archeologists, or gladiators). This rigidity sometimes manifested itself in overrepetition of very similar paintings: between 1945 and 1962, de Chirico painted 18 nearly identical versions of Les Muses inquiétantes, while the original work dated back from 1917 ! De Chirico became even famous - or infamous for his interest in copying his own works, and antedating

\begin{tabular}{ll}
\hline KARGER & ( ) 2003 S. Karger AG, Basel \\
Fax +41613061234 & $0014-3022 / 03 / 0504-0189 \$ 19.50 / 0$ \\
$\begin{array}{l}\text { E-Mail karger@karger.ch } \\
\text { www.karger.com }\end{array}$ & $\begin{array}{l}\text { Accessible online at: } \\
\text { www.karger.com/ene }\end{array}$
\end{tabular}

Prof. Julien Bogousslavsky

Department of Neurology, CHUV

CH-1011 Lausanne (Switzerland)

Tel. +4121314 1220, Fax +41213141231

E-Mail Julien.Bogousslavsky@chuv.hospvd.ch 
them, making what can be called 'false originals'. This took mainly place in the last third of his life, when the attenuation or disappearance of his complex inner imagery seemed to barren any renewal of inspiration. Indeed, copying his own previous production replaced his characteristic sudden changes of style, which had been so typical of his evolution until the mid 1930s. This corresponds well to an apparent improvement of the complex malaises and visual episodes, which had been so well described by the painter in his writing such as Hebdomeros [5]. An up to now forgotten report by the great collector René Gaffé [7], who had bought de Chirico's own copy of Apollinaire's book Calligrammes, illustrated with lithographs by him in 1930, summarizes very well the complex visual episodes shown by the painter: 'For the lithographs under your eyes, he told me, I took inspiration from memories of the years 1913-1914. I had just met the poet. I was reading with avidity his verses in which suns and stars are fre- quently mentioned. At the same time, by a mental phenomenon, which is familiar to me and which is often reflected in my paintings, I was thinking of Italy, its towns and its mines. Suddenly, for me, through a lightning which makes you discover beside you the object you are thinking of, these suns and stars were coming back on earth like peaceful emigrants. They were probably off in the sky, since I was seeing them being switched on at the door of many houses. Was it unreasonable to establish on the fountain of my mind and on the state of my visions the lithographs which would coexist with the poetic scales played by Apollinaire as a true visionary?'

Blanke and Landis [2] emphasize how a neurological condition undoubtedly influenced the work of one of the greatest modern artists. Since a disease may help understand artistic features, and art may help understand the manifestations of diseases, further studies in the 'neurology of art' would certainly be interesting and useful.

\section{References}

1 Kertesz A, Hillis A, Munoz DG: Frontotemporal degeneration, Picks' disease, Pick complex, and Ravel. Ann Neurol 2003;54(suppl 5):S1S2.

2 Blanke O, Landis T: The metaphysical art of Giorgio de Chirico. Migraine or epilepsy? Eur Neurol 2003;50:191-194.

3 Fuller IN, Gale MV: Migraine aura as artistic inspiration. BMJ 1988;297:1670-1672.
4 Podoll K, Robinson D, Nicola U: The migraine of Giorgio de Chirico. 1. History of illness. Neurol Psychiatr Brain Res 2001;9:139-156.

5 De Chirico G: Hebdomeros. Paris, Edition du Carrefous, 1929.

6 De Chirico G: Mémoires. Paris, La Table Ronde, 1962.

7 Gaffé R: Giorgio de Chirico le voyant. Bruxelles, Private edition, 1946 